\title{
Prevalence of dyslipidemia in children from 2 to 9 years old
}

\author{
Prevalência de dislipidemias em crianças de 2 a 9 anos \\ Prevalencia de dislipidemias en niños de 2 a 9 años
}

Josianne Alves de Freitas Maia' ORCID: 0000-0002-3617-4411

Francisco José Maia Pinto" ORCID: 0000-0003-2976-7857

Francisco Regis da Silva" ORCID: 0000-0001-5470-2874

Débora Sâmara Guimarães Dantas" ORCID: 0000-0003-1954-1600

Rafaella Maria Monteiro Sampaio" ORCID: 0000-0001-9994-1916

Edna Maria Camelo Chaves" ORCID: 0000-0001-7752-3924

Aline Ávila Vasconcelos" ORCID: 0000-0002-3047-4093

José Auricélio Bernardo Cândido" ORCID: 0000-0003-3327-8861

Sociedade Beneficente São Camilo, Hospital São Raimundo. Limoeiro do Norte, Ceará, Brazil.

"Universidade Estadual do Ceará. Fortaleza, Ceará, Brazil.

How to cite this article: Maia JAF, Pinto FJM, Silva FR, Dantas DSG, Sampaio RMM, Chaves EMC, et al. Prevalence of dyslipidemia in children from 2 to 9 years old Rev Bras Enferm. 2020;73(Suppl 4):e20190759. doi: http://dx.doi.org/10.1590/0034-7167-2019-0759

Corresponding author: Josianne Alves de Freitas Maia E-mail: drajosianne@hotmail.com

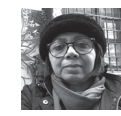

EDITOR IN CHIEF: Antonio José de Almeida Filho ASSOCIATE EDITOR: Hugo Fernandes

\section{ABSTRACT}

Objective: Analyze the occurrence of dyslipidaemia and associated factors in children aged 2 to 9 years. Method: Cross-sectional study, carried out with 700 children, in a region of Northeast Brazil. For comparison of means, Student's $t$ test was used; and, for the comparison of medians, the Mann-Whitney test. Results: A prevalence of dyslipidaemia of $68.4 \%$ was found. In isolation, the majority had a level of: total desirable cholesterol (386; 55.1\%), undesirable lipoprotein cholesterol $(376 ; 53.7 \%)$, low density lipoproteins - desirable cholesterol (514; $73.4 \%$ ) and desirable triglyceride $(509 ; 72.7 \%)$. In the final multivariate model, only the variable "preschool age" was significant (prevalence ratio $=1.14$ ), indicating that these children are more likely to have dyslipidaemia than those of school age. Conclusion: An association was found between dyslipidaemia and preschool age. The need for programs and strategies to better understand this problem is indicated, in addition to preventing early coronary diseases. Descriptors: Dyslipidaemias; Child; Preschool; Risk Factors; Prevalence.

\section{RESUMO}

Objetivo: Analisar a ocorrência de dislipidemias e fatores associados em crianças de 2 a 9 anos. Métodos: Estudo transversal, realizado com 700 crianças, em uma região do Nordeste brasileiro. Para comparação de médias, utilizou-se o teste $t$ de Student; e, para a comparação de medianas, o teste de Mann-Whitney. Resultados: Encontrou-se uma prevalência de dislipidemia de $68,4 \%$. Isoladamente, a maioria apresentou nível de: colesterol total desejável (386; 55,1\%), colesterol da lipoproteína não desejável (376; 53,7\%), lipoproteínas de baixa densidade - colesterol desejável $(514 ; 73,4 \%)$ e triglicerídeo desejável $(509 ; 72,7 \%)$. No modelo multivariado final, apenas a variável "idade pré-escolar" foi significante (razão de prevalência $=1,14$ ), indicando que essas crianças têm mais chance de ter dislipidemia do que aquelas na idade escolar. Conclusão: Encontrou-se associação entre a dislipidemia e a idade pré-escolar. Indica-se a necessidade de programas e estratégias para melhor conhecimento sobre esse problema, além da prevenção de agravos coronarianos precoces. Descritores: Dislipidemias; Criança; Pré-Escolar; Fatores de Risco; Prevalência.

\section{RESUMEN}

Objetivo: Analizar la ocurrencia de dislipidemias y factores asociados en niños de 2 a 9 años. Métodos: Estudio transversal, realizado con 700 niños, en una región del noreste de Brasil. Para comparar medias se utilizó la prueba t de Student; y, para la comparación de medianas, la prueba de Mann-Whitney. Resultados: Se encontró una prevalencia de dislipidemia del $68,4 \%$. De forma aislada, la mayoría presentó un nivel de: colesterol deseable total (386; $55,1 \%)$, colesterol de lipoproteínas indeseables (376;53,7\%), lipoproteínas de baja densidad - colesterol deseable $(514 ; 73,4 \%)$ y triglicéridos deseables $(509 ; 72,7 \%)$. En el modelo multivariado final, solo la variable "edad preescolar" fue significativa (razón de prevalencia $=1,14$ ), lo que indica que estos niños tienen más probabilidades de tener dislipidemia que los que están en edad escolar. Conclusión: Se encontró asociación entre dislipidemia y edad preescolar. Se indica la necesidad de programas y estrategias para comprender mejor este problema, además de prevenir enfermedades coronarias precoces.

Descriptores: Dislipidemias; Niño; Preescolar; Factores de Riesgo; Predominio. 


\section{INTRODUCTION}

Dyslipidaemia consists of changes in the lipid profile, expressed by elevated levels of total cholesterol (TC), triglycerides (TG) and low-density lipoprotein (LDL-C) as well as low levels of high density lipoprotein (HDL-c). It may occur either alone or in combinations, or it may be hereditary or acquired ${ }^{\left({ }^{1.2}\right)}$. Children with dyslipidaemia mostly denote a monogenic or idiopathic manner, associated with risk factors or multifactorial aspects,

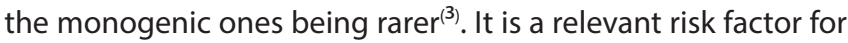
the development of atherosclerosis in children ${ }^{(1)}$. It is known that, among children with dyslipidaemia, half will become adult dyslipidaemia, a phenomenon known as tracking, that is, high cholesterol levels will persist into adulthood, increasing the risks of coronary diseases ${ }^{(4)}$.

Population Brazilian studies show, according to region and criterion, prevalence of $10 \%$ to $23.5 \%$ of dyslipidaemia in children and adolescents. This suggests that childhood should be increasingly considered a concern, as it is a strategic phase in the prevention of atherosclerosis at the population level, considering that life habits (important causes of cardiovascular disease risk modulation - CVD) are formed in this phase $\mathrm{e}^{(5)}$. In the city of Fortaleza, Ceará, the prevalence of dyslipidaemia in children and adolescents is $66.1 \%{ }^{(6)}$. In Brazil, regional studies point to high prevalence of childhood dyslipidaemia: increased total cholesterol, $86 \%{ }^{(7)}$.

CVD is the major cause of morbimortality, both in developed and developing countries, being responsible for $31.8 \%$ of the causes of death in adults in $\mathrm{Brazi}^{(8)}$. There are several risk factors associated with the development of cardiovascular diseases, such as smoking, obesity and dyslipidaemia ${ }^{(1)}$. Specifically, dyslipidaemia is the biggest impact factor in the development of atherosclerotic disease, in particular the presence of increased concentrations of low density lipoprotein (LDL)(1). Thus, the formation of atherosclerotic plaque, which begins in childhood, progresses in adolescence and adulthood. In view of the involvement of non-modifiable factors (genetics, age and gender) and modifiable factors (lifestyle), research and prevention in early stages of their formation is justified ${ }^{(9)}$.

The epidemiological assessment of the lipid profile is considered relevant as a collective health action for the promotion of public health policies aimed at preventing and reducing cardiovascular risk factors in the population ${ }^{(10)}$. In addition, in Brazil, population data on changes in plasma lipids are scarce - in general, with series restricted to small samples or very limited geographical areas ${ }^{(11)}$.

\section{OBJECTIVE}

Analyze the occurrence of dyslipidaemia and associated factors in children aged 2 to 9 years old in a region of north-eastern Brazil.

\section{METHODS}

\section{Ethical aspects}

This study was approved by the Ethics Committee of the State University of Ceará (UECE).

\section{Design, study location and period}

Cross-sectional study, conducted with children aged 2 to 9 years, 11 months and 29 days, as established in child care services $^{(12)}$, seen at a paediatric outpatient clinic belonging to the 10th Health Region ${ }^{(13)}$ from the state of Ceará, from February to July 2016. This Health Region consists of 11 bordering municipalities, comprising Alto Santo, Erere, Iracema, Jaguaribara, Jaguaribe, Quixeré, Pereiro, Potiretama, Limoeiro do Norte, Tabuleiro do Norte and São João do Jaguaribe, and its creation took place with the purpose of integrating the organization, planning and execution of health actions and services.

\section{Population or sample: inclusion and exclusion criteria}

The probabilistic sample was 703 children, calculated based on the prevalence of $66.1 \%{ }^{(6)}$, sampling error of $3.5 \%$ and significance level of $5 \%$, reducing to 700 children after three losses. The study included children whose parents agreed to participate in the research, after being properly informed. The exclusion criteria considered were: children who had diseases and/or the use of drugs that caused secondary dyslipidaemia and, consequently, interfered in the assessment of the lipid profile. In addition, those who were unable to position themselves for correct weight and/ or height verification would be excluded.

\section{Study protocol}

For data collection, a semi-structured questionnaire applied by the researcher was used. The outcome was considered as dyslipidaemia in children (yes; no) based on the lipid profile, according to criteria established by the Brazilian Society of Cardiology(5). The associative variables were sociodemographic, nutritional and protective (breastfeeding and birth weight) ${ }^{(14)}$.

The weighing of the children was carried out on an adulttype mechanical platform scale, from the Welmy brand ${ }^{\circ}$, with a graduation of $100 \mathrm{~g}$, previously regulated and given to each new weighing, supported on a flat, smooth surface and away from the wall, with a maximum capacity of $150 \mathrm{~kg}$, divisions of $100 \mathrm{~g}$, with anthropometric ruler in anodized aluminium and divisions of $0.5 \mathrm{~cm}$. The children were positioned in the center of the equipment, with their backs to the scale, barefoot, standing, with their arms extended along their bodies, wearing very light clothes, such as shorts, panties or underpants and being with the guardians $\mathrm{s}^{(12)}$. Current body mass in kilograms $(\mathrm{kg})$ and height measured in centimetres $(\mathrm{cm})$ were considered, with the children in the standing posture, Frankfurt position and with the head free of accessories ${ }^{(12)}$.

The Brazilian Society of Paediatrics recommends the assessment of the lipid profile in children aged 2 to 10 years, as a routine for all children who express: positive family history of premature CVD (parents and grandparents) or other CVD risk factors; or who have first-degree relatives with a TC greater than $240 \mathrm{mg} / \mathrm{dl}$ and a TG greater than $400 \mathrm{mg} / \mathrm{dl}$, with an unknown family history; or, still, that express diseases or clinical signs indicative of the need for such an evaluation ${ }^{(9,12)}$.

To perform the lipid profile, which includes the dosage of 
four parameters - CT, HDL c, LDL-c and TG - $4 \mathrm{ml}$ of blood were collected, with fasting for 12 hours being recommended, except for water and medications. The biochemical dosage of the lipid profile was carried out in a clinical analysis laboratory, Jaguaribano Laboratory of Clinical Analysis, located in the city of Limoeiro do Norte, Ceará.

The material was collected in a vacuum, dried tube and examined in an automatic equipment, Labtest', Labmaxplenno model. CT and TG were performed using the colorimetric method (enzymatic trinder); and $\mathrm{HDL}-\mathrm{C}$, performed using a colorimetric method (accelerator - selective detergent). To obtain safe results, daily quality control was carried out on two levels: normal and altered. Repetition parameters were used for biochemical measurements, with values above the reference. LDL-c was calculated using the Friedwald formula, given by, using fasting TG values. In order to categorize the study participants, inadequacy cut-off points were used, according to the V Brazilian Guideline on Dyslipidaemia ${ }^{(5)}$.

\section{Analysis of results and statistics}

The data were stored in the Microsoft Office Excel ${ }^{\circledR}$ program, version 11.0, and processed using the statistical program PASW (Predictive Analytics Software for Windows), version 17.0.

Data analysis was performed in a descriptive manner, using absolute and relative frequencies and measures of median, mean and standard deviation. Inferential analysis involved the association between the outcome represented by dyslipidaemia (yes; no) and the associative variables related to sociodemographic, nutritional and protective factors (breastfeeding and birth weight).

In the unadjusted analysis, the Wald chi-square test was used, with a significance level of $5 \%$. As a criterion for entering the model, variables that registered a descriptive level were selected $p<0.20$; and, to remain in the adjusted multivariate model, only those with a $p$-value $<0.05$. Poisson regression, with robust variance, was used as an estimate by point and by interval of the prevalence ratio $(P R)^{(14)}$. According to Petersen and Deddens ${ }^{(15)}$, the model converges easily, and adequate PR estimates are obtained in the face of categorical variables. Poisson regression with robust variance produces adequate estimates of the prevalence ratio, in addition to the established confidence intervals regardless of the adopted prevalence ${ }^{(16-17)}$.

The averages of quantitative variables in relation to dyslipidaemia in children were compared, and the medians for qualitative associative variables, using Student's $t$ and Mann-Whitney tests, respectively, with a significance level of $5 \%$.

\section{RESULTS}

The sample of 700 children stratified in relation to the diagnosis of dyslipidaemia showed: yes $(479 ; 68.4 \%)$ and no $(221$; $31.6 \%)$. Most of the children were descendants of farmers (261; $55.6 \%)$, with parents' education related to elementary school (247; 56.8\%), eutrophic $(233 ; 46.6 \%)$, who had mixed or partial breastfeeding $(31 ; 50.8 \%)$ and in pre-school age $(273 ; 57.0 \%)$. In the unadjusted model $(p<0.20)$, the variables were considered: mother's profession ( $p=0.107)$, parents' education $(p=0.059)$, children's nutritional diagnosis $(p=0.119)$, type of breastfeeding $(p=0.052)$ and children's school age $(p=0.012)$ (Tables 1 and 2$)$.

In the final model, only the variable "children's age" was significant $(p=0.012)$, indicating that those in the preschool age profile were 1.14 times more likely to have dyslipidaemia than children in the school age group (Table 3).

Table 1 - Dyslipidaemia and unadjusted prevalence ratio of children (sociodemographic variables), Limoeiro do Norte, Ceará, February to July 2016

\begin{tabular}{|c|c|c|c|c|c|c|c|c|c|}
\hline \multirow{2}{*}{ Variables } & \multicolumn{4}{|c|}{ Dyslipidaemia* } & \multirow{2}{*}{ PR } & \multicolumn{3}{|c|}{$\mathrm{Cl}(95 \%)$} & \multirow{2}{*}{$p$ value } \\
\hline & Yes & $\%$ & No & $\%$ & & & & & \\
\hline Mother's profession & & & & & & & & & 0.107 \\
\hline Others & 208 & 72.0 & 81 & 28.0 & 1.09 & 0.98 & - & 1.20 & \\
\hline Agriculture & 261 & 66.2 & 133 & 33.8 & 1 & & & & \\
\hline Father's profession & & & & & & & & & 0.661 \\
\hline Others & 226 & 67.7 & 108 & 32.3 & 0.98 & 0.88 & - & 1.08 & \\
\hline Agriculture & 223 & 69.3 & 99 & 30.7 & 1 & & & & \\
\hline Mothers' income & & & & & & & & & 0.583 \\
\hline$>2 \mathrm{~ms}$ & 19 & 73.1 & 7 & 26.9 & 1.09 & 0.85 & - & 1.38 & 0.508 \\
\hline 1 a $2 \mathrm{~ms}$ & 150 & 70.8 & 62 & 29.2 & 1.05 & 0.94 & - & 1.17 & 0.370 \\
\hline$<1 \mathrm{~ms}$ & 299 & 67.3 & 145 & 32.7 & 1 & & & & \\
\hline Fathers' income & & & & & & & & & 0.564 \\
\hline$>2 \mathrm{~ms}$ & 55 & 69.6 & 24 & 30.4 & 0.97 & 0.81 & - & 1.16 & 0.731 \\
\hline 1 a $2 \mathrm{~ms}$ & 301 & 67.2 & 147 & 32.8 & 0.93 & 0.82 & - & 1.06 & 0.295 \\
\hline$<1 \mathrm{~ms}$ & 92 & 71.9 & 36 & 28.1 & 1 & & & & \\
\hline Parents' education & & & & & & & & & 0.059 \\
\hline Elementary & 247 & 67.3 & 120 & 32.7 & 0.83 & 0.71 & - & 0.97 & 0.021 \\
\hline High School & 150 & 67.6 & 72 & 32.4 & 0.84 & 0.71 & - & 0.99 & 0.034 \\
\hline Higher education & 38 & 80.9 & 9 & 19.1 & 1 & & & & \\
\hline Origin of children & & & & & & & & & 0.879 \\
\hline Urban & 190 & 68.1 & 89 & 31.9 & 0.99 & 0.89 & - & 1.10 & \\
\hline Rural & 289 & 68.6 & 132 & 31.4 & 1 & & & & \\
\hline
\end{tabular}


Table 2 - Dyslipidaemia and unadjusted prevalence ratio of children (clinical variables), Limoeiro do Norte, Ceará, February to July 2016

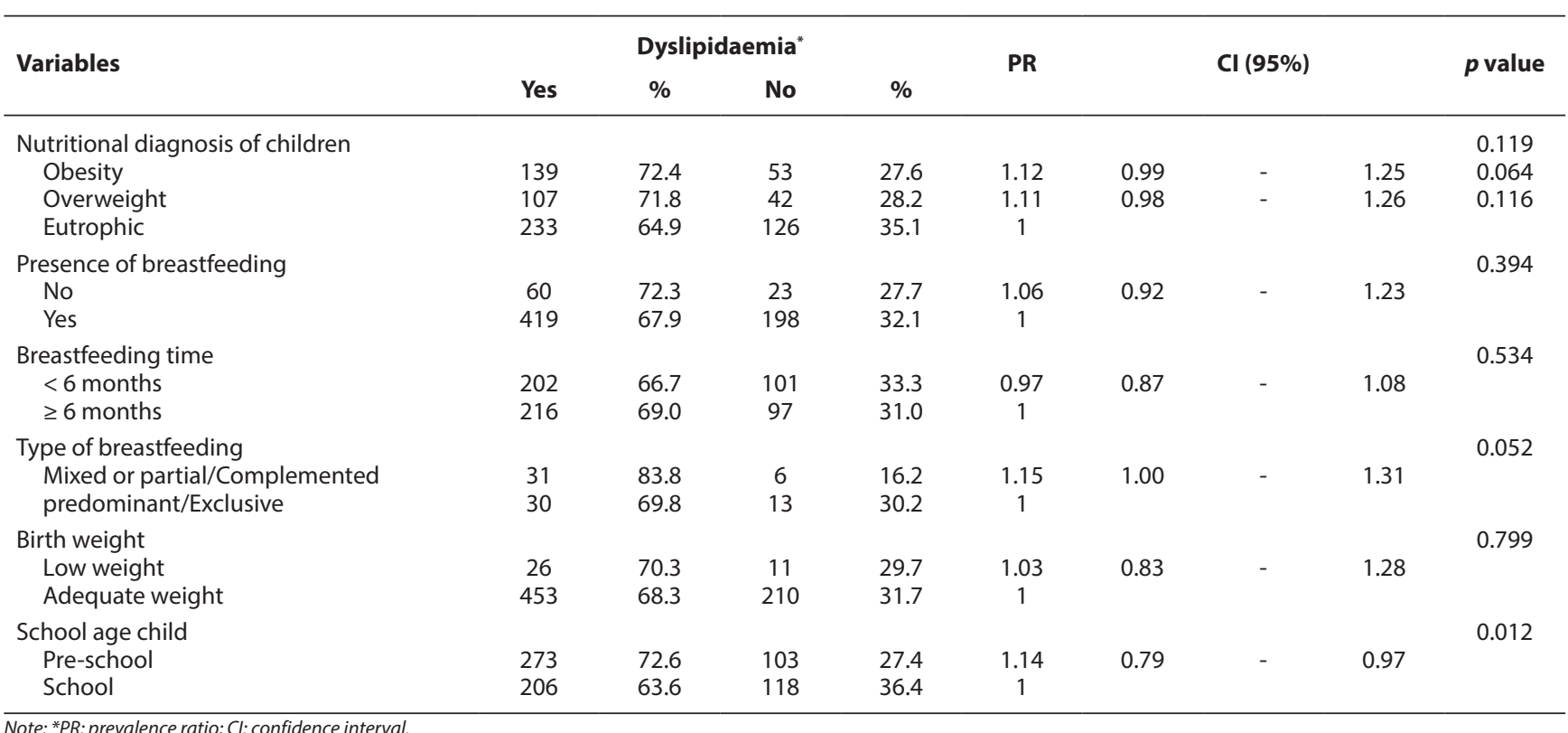

Table 3 - Adjusted prevalence ratio, in the final model, of dyslipidaemia in children, Limoeiro do Norte, Ceará, February to July 2016

\begin{tabular}{|c|c|c|c|c|}
\hline \multirow{2}{*}{$\begin{array}{l}\text { Variables } \\
\text { Age }\end{array}$} & \multirow[t]{2}{*}{ PR } & \multicolumn{2}{|c|}{$\begin{array}{l}\mathrm{Cl}(95 \%) \\
\text { adjusted }\end{array}$} & \multirow{2}{*}{$\begin{array}{c}\boldsymbol{p} \text { value } \\
0.012\end{array}$} \\
\hline & & & & \\
\hline Pre-school & 1.14 & 0.79 & 0.97 & \\
\hline School & 1 & & & \\
\hline
\end{tabular}

Table 4 - Comparison of means of variables in relation to dyslipidaemia in children, Limoeiro do Norte, Ceará, February to July 2016

\begin{tabular}{lccccc}
\hline & Dyslipidaemia & $\mathbf{n}$ & Mean & SD & p value* \\
\hline Abdominal & NO & 221 & 55.07 & 7.34 & 0.385 \\
circumference & YES & 479 & 55.62 & 8.63 & \\
BMI & NO & 220 & 17.470 & 2.62 & 0.056 \\
& YES & 479 & 17.906 & 3.13 & \\
\hline
\end{tabular}

Note: *Use of Student's t test; SD: standard deviation.

Table 5 - Comparison of medians of variables in relation to dyslipidaemia in children, Limoeiro do Norte, Ceará, February to July 2016

\begin{tabular}{lccccc}
\hline & Dyslipidaemia & $\mathbf{n}$ & Median & SD & p value* \\
\hline \multirow{2}{*}{ Age } & NO & 221 & 6.20 & 2.26 & $\mathbf{0 . 0 2 0}$ \\
\multirow{3}{*}{ Birth weight } & YES & 479 & 5.40 & 2.35 & \\
& NO & 221 & 22.40 & 7.88 & 0.173 \\
& YES & 479 & 21.30 & 9.31 & \\
\hline
\end{tabular}

Note: *Use of the Mann-Whitney test; SD: standard deviation.

The median was used to represent the variables: age, weight, LDL-C and TG (Table 4). For the other variables (height, waist circumference, BMI, CT, HDL-c and birth weight), the arithmetic mean was applied (Table 4).

Regarding the outcome represented by dyslipidaemia, a statistically significant difference was obtained by Student's $t$ test, which was not significant ( $p>0.05$ ), for the variable "abdominal circumference" (Table 4).
When testing the outcome with the variables "age" and "birth weight", it was found that only "age" showed statistical significance ( $p<0.05)$, using the Mann-Whitney test (Table 5).

\section{DISCUSSION}

Dyslipidaemia was observed in $68.4 \%$ of the studied population. In isolation, the majority had levels of: desirable TC (386: 55.1\%), undesirable HDL-c (376: 53.7\%), desirable LDL-c (514: 73.4\%) and desirable TG (509: 72.7\%).

The results of this research showed positive effects in determining the lipid profile, as this is confirmed in other studies according to the age groups: 6 to 9 years $(48.1 \%)^{(17)}, 2$ to 18 years (16\% to $34 \%)^{(18)}, 6$ to 17 years old $(12.5 \%)^{(19)}$. The following factors are involved in altering the lipid profile: genetics, physical inactivity, atherogenic diet, exposure to tobacco, obesity and dyslipidaemia. Childhood research is needed to prevent complications, morbidities and mortality in adulthood ${ }^{(20)}$.

It is noteworthy that the first 1,000 days of life - from conception to 2 years of age - can be considered the modulating period of growth and anatomical and functional development of the organism ${ }^{(21)}$. This suggests investment in the formation of good eating habits, aiming at the prevention of chronic noncommunicable diseases, which currently affect childhood and will have an impact on adult life ${ }^{(22)}$. The main objective of universal screening is to identify cases of familial hypercholesterolemia and the use of non-HDL-c in the identification of children with the components of the metabolic syndrome ${ }^{(23)}$.

In this research, according to the findings of dyslipidaemia, it was shown that they may also be affecting mainly children from rural areas, who currently, have the same lifestyle as children in urban areas. This occurs as a result of more sedentary habits, industrialized foods and access to the most diverse forms of electronic entertainment, which make children exercise less, causing a decrease in HDL-c levels. This situation is configured 
as a serious collective health problem, which may have future repercussions for the adult life of these children.

It is also worth noting that children with inadequate birth weight expressed dyslipidaemia. Low birth weight has a great influence on infant morbidity and mortality ${ }^{(24)}$, and this clinical condition at birth indicates a possible relationship with the development of obesity, dyslipidaemia, arterial hypertension and type 2 diabetes ${ }^{(25)}$. Studies show that low birth weight often progresses with increased TG and increased LDL-( $\mathrm{C}^{(26)}$, being that adults born at term and with low weight gain a higher percentage of fat mass than those born with adequate weight ${ }^{(27)}$. A study carried out in Argentina with indigenous children showed a high prevalence of dyslipidaemia, but not associated with overweight and obesity, suggesting the existence of genetic factors in this population ${ }^{(28)}$. This fact shows that, despite being a different population from the one investigated in the present study, there is a high prevalence of dyslipidaemia, suggesting that it is a public health problem in different people/countries. It is also noteworthy that the adequate weight at birth reflects the improvement of public health care policies for pregnant women and their concepts, through the prenatal actions in the Family Health Strategy, contributing to the improvement of healthy birth and rates of adequate Brazilian children.

When relating dyslipidaemia to breastfeeding, there was statistical significance in the borderline; and despite that, it was considered in the model, as mixed or supplemented breastfeeding has a $15 \%$ greater chance of developing dyslipidaemia than those who were exclusively breastfed. In this study, however, there was no evidence to link breastfeeding to dyslipidaemia. It is known that the practice of breastfeeding is one of the strategies to reduce neonatal and infant morbimortality. In the present investigation, the majority of children were breastfed.

HDL-c was the fraction of the lipid profile that was altered (53.7\%). It is known that HDL-c represents protection against the risk of developing CVD, but previous studies have shown a lower prevalence than that found in this research $(35.1 \%)^{(7)}$. Research carried out with 893 children and young adults suggests that TG and HDL-c can be used in the early identification of young people who need a more aggressive intervention to prevent cardiovascular diseases ${ }^{(29)}$. Cohort study conducted with data from the years 2004 and 2008 in children aged 5 and 9 years showed a prevalence of altered HDL-c in $35.1 \%$ and $67.6 \%$, respectively ${ }^{(5)}$.
It is noteworthy that the beginning of physical activity in childhood improves the lipid profile, contributing to the reduction of overweight and obesity and, consequently, being able to collaborate for the continuity of this practice in adulthood.

The study of dyslipidaemia in children from 2 to 9 years old pointed to preschool age ${ }^{(30-32)}$ as the group most likely to develop dyslipidaemia. This indicates that the determination of the lipid profile is valid as a way to prevent early coronary diseases.

\section{Study limitations}

This study had limitations related to sample selection, as it is a health region with certain particularities, such as socioeconomic, epidemiological, demographic, cultural, among others. This limitation is very common in studies on dyslipidaemia in children, as it involves the measurement of the lipid profile. Furthermore, it has limitations, as it is a local sample, in a cross-sectional study, highlighting only the cause-effect relationship.

\section{Contribution to the area of nursing, health or public policy}

This research was pioneering in this health region when investigating the lipid profile in children from 2 to 9 years old, exclusively, regardless of the overweight factor.

These results are expected to contribute to epidemiological data on dyslipidaemia and associated risk factors for the state of Ceará. Nationally, this study may guide the planning of public maternal and child health actions and policies.

\section{CONCLUSION}

Age was a major factor in the association with dyslipidaemia and evidenced the need for health education in the family and school environment, resulting in public health promotion actions and policies.

This research provided epidemiological foundations to highlight the need for actions of food and nutrition education, as well as health promotion programs and policies, aimed at this audience, which include the practice of physical activity, exclusive breastfeeding and complementary feeding healthy, in order to prevent such changes, since they can remain during adolescence and adulthood. Therefore, it is necessary to build scientific knowledge about dyslipidaemia in children, in addition to carrying out additional studies to assess the influx of information obtained.

\section{REFERENCES}

1. Quadros TMB, Gordia AP, Silva RCR, Silva LR. Predictive capacity of anthropometric indicators for dyslipidemia screening in children and adolescents. J Pediatr 2015;91(5):455-63. doi: 10.1016/j.jped.2014.11.006

2. Slhessarenko N, Jacob CM, Azevedo RS, Fontes CJ, Novak GV, Andriolo A. Serum lipids in Brazilian children and adolescents: determining their reference intervals. BMC Public Health 2015;15(18). doi: 10.1186/s12889-015-1359-4

3. Espinheira MC, Vasconcelos C, Medeiros AM, Alves AC, Bourbon M, Guerra A. Hipercolesterolemia - uma patologia com expressão desde a idade pediátrica. Rev Port Cardiol 2013;32(5):379-86. doi: 10.1016/j.repc.2012.09.008

4. Ramos AT, Carvalho DF, Gonzaga NC, Cardoso AS, Noronha JAF, Cardoso MAA. Perfil lipídico em crianças e adolescentes com excesso de peso. Rev Bras Cresc Desenvol Hum. 2011;21(3):780-8. 
5. Faludi AA, Izar MCO, Saraiva JFK, Chacra APM, Bianco HT, Afiune Neto A, et al. Atualização da Diretriz Brasileira de Dislipidemias e Prevenção da Aterosclerose - 2017. Atualização da Diretriz Brasileira de Dislipidemias e Prevenção da Aterosclerose - 2017. Arq Bras Cardiol 2017;109(2 Suppl 1):1-76.

6. Bezerra AC, Sampaio HAC, Melo MLP, Maia CSC, Almeida PC. Associação entre dislipidemia e excesso de peso de crianças e adolescentes atendidos em uma unidade de saúde. Rev Baiana Saúde Pública 2011;35(2):348-62. doi: 10.22278/2318-2660.2011.v35.n2.a310

7. Magalhães TCA, Vieira SA, Priore SE, Ribeiro AQ, Franceschini SCC, Sant'ana LFR. Fatores associados à dislipidemia em crianças de 4 a 7 anos de idade. Rev Nutr 2015;28(1):17-28. doi: 10.1590/1415-52732015000100002

8. Gabriela F, Costa RAC, Saori SK, Rogerio S, Figueiredo EP, Biscegli Jl. Prevalência de dislipidemia em população infantil com cardiopatia congênita. Arq Bras Cardiol. 2013;101(3):273-276. doi: 10.5935/abc.20130174

9. Da Silva PC, Torres F. Hipercolesterolemia e o desenvolvimento da aterosclerose: revisão de literatura. Rev Científ Fac Educ Meio Amb. 2015;6(1):48-58. doi: 10.31072/rcf.v6i1.304

10. Riccioppo GM, Lopes PJ, Mello FM, Lobo MDM, Mara FR. Prevalência de Dislipidemia Segundo Estado Nutricional em Amostra Representativa de São Paulo. Arq Bras Cardiol. 2014;103(6):476-84. doi: 10.5935/abc.20140156

11. Faria Neto JR, Bento VFR, Baena CP, Olandoski M, Gonçalves LGO, Abreu GA, et al. ERICA: prevalence of dyslipidemia in Brazilian adolescents. Rev Saúde Pública. 2016;50(suppl 1):10s. doi: 10.1590/s01518-8787.2016050006723

12. Sociedade Brasileira de Pediatria (SBP). Obesidade na infância e adolescência: Manual de orientação. Departamento Científico de Nutrologia. 2. ed. São Paulo: SBP; 2012.

13. Ministério da Saúde (BR). Decreto n 7.508, de 28 de junho de 2011. Regulamenta a Lei no 8.080, de 19 de setembro de 1990, para dispor sobre a organização do Sistema Único de Saúde - SUS, o planejamento da saúde, a assistência à saúde e a articulação interfederativa e dá outras providências. Brasília (DF): Ministério da Saúde; 2011.

14. Siqueira BC, Lazaro CM, Couto OMI. Fatores associados ao aleitamento materno exclusivo nos primeiros seis meses de vida no Brasil: revisão sistemática. Rev Saúde Pública. 2015;49(91):1-16. doi: 10.1590/S0034-8910.2015049005971

15. Coutinho, Leticia M.S, Scazufca, Marcia, Menezes, Paulo R. Métodos para estimar razão de prevalência em estudos de corte transversal. Rev. Saúde Pública 2008;42(6):992-8. doi: 10.1590/S0034-89102008000600003

16. Petersen MR, Deddens JA. A comparison of two methods for estimating prevalence ratios. BMC Med Res Methodol. 2008;8(9):1-9. doi: $10.1186 / 1471-2288-8-9$

17. Barros AJD, Hirakata VN. Alternatives for logistic regression in cross-sectional studies: an empirical comparison of models that directly estimate the prevalence ratio. BMC Med Res Methodol. 2003;3(21):1-13. doi: 10.1186/1471-2288-3-21

18. Reis RCP, Silva JLP, Colosimo EA, Barros AJD. Estudo comparativo de métodos para estimação da razão de prevalência. $19^{\circ}$ SINAPE, 2010.

19. Ribas SA, Silva LCS. Fatores de risco cardiovascular e fatores associados em escolares do Município de Belém, Pará, Brasil. Cad Saúde Pública. 2014;30(3):577-586. doi: 10.1590/0102-311X00129812

20. Juiz Cl, Montagna MG, Jarruz ML, Córdoba R, Arminda S, Guanca H. Perfil lipídico y circunferencia de cinturas de niños/as y adolescentes con esta artículo original do nutricional adecuado de la ciudad de Salta - Argentina - 2011. Actualiz Nutrición 2013;14(4):299-306

21. Pires A, Martins P, Pereira AM, Silva PV, Marinho J, Marques M, Castela E, et al. Insulino-resistência, Dislipidemia e Alterações Cardiovasculares num Grupo de Crianças Obesas. Arq Bras Cardiol. 2015;104(4):266-273. doi: 10.5935/abc.20140206

22. Flumian RP. Perfil lipídico de crianças obesas assistidas na rede pública de saúde de Três Lagoas, MS [Dissertação]. Campo Grande (MS): Universidade Federal de Mato Grosso do Sul, Campo Grande; 2013.

23. Pires MMS. Competências do pediatra na puericultura. $7^{\circ}$ Curso Nestlé de Atualização em Pediatria, Fortaleza: Sociedade Brasileira de Pediatria, 2014.

24. Liberal EF, Vasconcelos MM. Saúde Escolar. Série pediatria. Rio de Janeiro: Guanabara Koogan, 2012. p. 202.

25. Bamba V. Update on Screening, Etiology, and Treatment of Dyslipidemia in Children. J Clin Endocrin Metab. 2014;99(9):3093-3102. doi: 10.1210/jc.2013-3860

26. Victora CG, Barros FC, Halpern R, Menezes AMB, Horta BL, Tomasi E, et al. Estudo longitudinal da população materno-infantil da região urbana do Sul do Brasil, 1993: aspectos metodológicos e resultados preliminares. Rev Saúde Pública. 1996;30(1):34-45. doi: 10.1590/\$0034-89101996000100005

27. Boguszewski MC, Mericq V, Bergada I, Damiani D, Belgorosky A, Gunczler P, et al. Latin American Consensus: children born small for gestational age. BMC Pediatrics. 2011;11(66):1-10. doi: 10.1186/1471-2431-11-66

28. Giuliano ICB, Caramelli B. Dislipidemia na infância e na adolescência. In: Lopes, AA. Cardiologia pediátrica. Barueri: Manole; 2011.

29. Lima MC, Dantas HF, Amorim RJM, Lira PIC. A restrição do crescimento fetal influencia a composição corporal na idade escolar? J Pediatr. 2011;87(1):29-35. doi: 10.1590/S0021-75572011000100006

30. Hirschler V. Dislipemia en Niños Indígenas argentinos que habitan a grandes altitudes. Actual Nutrición 2013;14(2):126-132.

31. Urbina EM, Khoury PR, McCoy CE, Dolan LM, Daniels SR, Kimball TR. Triglyceride to HDL-c ratio and increased stiffness in children, adolescents, and young adults. Pediatrics. 2013;131(4):1082-90. doi: 10.1542/peds.2012-1726

32. Vaz AFC, Figueredo LZP, Motta AB. Problemas de comportamento, ansiedade e habilidades sociais em crianças pré-escolares. Psicol: Teor Prática 2020;22(1):161-184. doi: 10.5935/1980-6906/psicologia.v22n1p185-207 